\title{
THE EFFECTIVENESS OF FERTILIZERS, PRE-SOWING SEEDS BAKTERYZATION AND THEIR COMBINATIONS IN THE GROWING TECHNOLOGIES OF NAKED OATS POLISSYA REGION
}

\author{
Berdnikov O. M., Potapenko L. V., Vasylchenko O. V., Vasylyuka N. D.
}

Institute of Agricultural Microbiology and AgroIndustrial Production NAAS, 97 Shevchenko str., Chernihiv, 14027, Ukraine

The effectiveness of pre-sowing seeds inoculation of naked oats with microbial preparation Polymyxobacteryn was studied in field experiments during 2010-2012 on different fertilization backgrounds. The equivalence of biological preparations impact on the crop productivity to the action of technical phosphorus applied at a dose of $20 \mathrm{~kg} / \mathrm{ha}$ was shown. The positive influence of bacteryzation was confirmed in lyzimeter experiments on reduction of nutrients leaching and water soluble humus through the soil profile beyond the root zone of plants.

Key words: naked oats, bacteryzation, Polymyxobacteryn, phosphorus, lyzimeter.

Nowadays the naked oats is gaining its importance for agricultural production and processing industry along with hulled oats. The potential yield of modern varieties of hulled oats is $7 \mathrm{t} / \mathrm{ha}$, whilefor naked oats that's $-5-6 \mathrm{t} / \mathrm{ha}$. Naked oats grain can be used for food and feed purposes as well as for infant food.

The high price of commodity grain of naked oats on the international market (200-240 USD/t) and the importance of culture in the domestic market of Ukraine imposes requirements for improving the cultivation technologies for this crop. Taking into the account the limited technical resources the optimization of fertilizer use through the application of factors, which increase plants' assimilation of active ingredients of fertilizers, including phosphorus as one of the most expensive agrochemical is of the big importance. At this, the application of microbial preparations might be highly perspective.

Thus, the aim of our research was to determine the possibility of using microbial preparation Polymyxobacteryn in growing technology of naked oats as an alternative to some part of phosphorus fertilizers.

Materials and methods. The study was conducted during 2010-2012 on sod-podzolic medium cultivated sandy soils in field and lyzimeter experiments in Institute of Agricultural Microbiology and Agroindustrial Production NAAS.

The main agrochemical soil characteristics are presented in table 1.

The data presented in table 1 indicates the medium soil acidity, low number of assimilated bases, low humus content, but a high level of easily hydrolyzed nitrogen and mobile phosphorus, the content of exchangeable potassium in the soil is low.

Scheme of experiments are presented in the corresponding tables. Pre-crop corn for silage. 


\section{Table 1. Agrochemical indicators of sod-podzolic sandy soils}

\begin{tabular}{|l|l|l|}
\hline \multirow{2}{*}{ Indicator } & \multicolumn{2}{|l|}{ Sapling depth, cm } \\
\cline { 2 - 3 } & $0-20$ & $20-40$ \\
\hline $\mathrm{pH}$ salt & 4,9 & 4,6 \\
\hline Hydrolytic acidity, mg-eqv/100 g of soil & 2,8 & 3,1 \\
\hline $\begin{array}{l}\text { Sum of assimilated basis, mg-eqv/100 g } \\
\text { of soil }\end{array}$ & 5,4 & 4,8 \\
\hline Humus (by Tyuryn), \% & 1,1 & 0,7 \\
\hline $\begin{array}{l}\text { Mobile forms of phosphorous, } \mathrm{mg} \mathrm{P}_{2} \mathrm{O}_{5} \\
\text { per kg of soil (by Kirsanov) }\end{array}$ & 179,0 & 179,0 \\
\hline $\begin{array}{l}\text { Exchangeable potassium, mg } \mathrm{K}_{2} \mathrm{O} \text { per } \mathrm{kg} \\
\text { soil } \\
\text { (by Maslova) }\end{array}$ & $60,0-70,0$ & $70,0-80,0$ \\
\hline
\end{tabular}

Fertilizers were applied in the form of ammonium nitrate, superphosphate and potassium chloride in spring prior to the spring pre-seeding cultivation. Presowing seeds inoculation was performed on the same day in accordance to the practical recommendations for the application of microbial preparations [3].

Area of field experiment $-72 \mathrm{~m}^{2}(6 \times 12 \mathrm{~m})$, accountable area $-40 \mathrm{~m}^{2}(4 \mathrm{x}$ $10 \mathrm{~m}$ ), 4-fold repetition.

Farming techniques for naked oats - common for the region. Variety - Skarb Ukrainy. Seeding rate -4.5 million / ha. Harvest - solid, per plot.

Weather conditions during the years of studies had significant differences. Thus, in 2010 in April-May the rainfall was only 69\% from the norm (long-term index $-97 \mathrm{~mm}$ ), in $2011-9.5 \%$, in $2012-68 \%$, which indicates that two of the studied years had insufficient moisture, while 2011 - was unfavorable. Overall, through the growing season the precipitation was lower when compared to the average (Table 2).

Results and discussion. The air temperature during the research years in average during the growing season had exceeded the long-term values by 2.8$4.3{ }^{\circ} \mathrm{C}$ while rainfall was lower by $15-21 \%$ comparing to the long-term indicators. That conditions had resulted in average $1.7 \mathrm{t} / \mathrm{ha}$ with a range from 1.48 to $2.02 \mathrm{t} / \mathrm{ha}$ in control (without fertilizer and inoculation). Inoculation of oat seeds with Polymyxobacteryn had contributed to the formation of grain yield of naked oats at the level of $3.01 \mathrm{t} / \mathrm{ha}$, that was 1.8 times higher comparing to control with slight differences between the years: from 3.1 to $2.88 \mathrm{t} / \mathrm{ha}(10 \%)$, while in the variants without inoculation the variation was $23 \%$ (Table 3 ). The effect of inoculation at our opinion is largely related to the intensification of the root system development (the root mass of bacterized plants was higher than in control by 17-22\%).

Therefore, seeds inoculation with Polymyxobacteryn at growing of naked oats after cultivated crops (corn) in variants without fertilization ensures a yield of $3 \mathrm{t} / \mathrm{ha}$. Even in years with insufficient moisture, the yield was higher comparing to control by $76 \%$. 
Table 2. Meteorological conditions during the growing season compared with average long-term indicators, 2010-2012

\begin{tabular}{|c|c|c|c|c|c|c|c|}
\hline \multirow[t]{2}{*}{ Indicator } & \multirow{2}{*}{$\begin{array}{l}\text { Years of } \\
\text { research }\end{array}$} & \multicolumn{4}{|c|}{ Months } & \multirow{2}{*}{$\begin{array}{l}\text { Total } \\
\text { rainfal } \\
1\end{array}$} & \multirow[b]{2}{*}{$\begin{array}{l}\text { Average } \\
\text { for } \\
\text { vegetatio } \\
\mathrm{n} \text { period }\end{array}$} \\
\hline & & April & May & June & July & & \\
\hline \multirow{4}{*}{$\begin{array}{l}\text { Rainfall, } \\
\mathrm{mm}\end{array}$} & 2010 & 17,9 & 49,1 & 28,3 & 93,3 & 188,6 & \\
\hline & 2011 & 1,8 & 7,4 & 57,3 & 124,0 & 190,5 & \\
\hline & 2012 & 42,2 & 23,4 & 84,7 & 52,7 & 203,2 & \\
\hline & $\begin{array}{l}\text { Average } \\
\text { indicator } \\
\text { for many } \\
\text { years }\end{array}$ & 47 & 50 & 71 & 71 & 239 & \\
\hline \multirow{4}{*}{$\begin{array}{l}\text { Average air } \\
\text { day } \\
\text { temperature } \\
,{ }^{\circ} \mathrm{C}\end{array}$} & 2010 & 10,0 & 17,6 & 22,6 & 26,3 & & 19,1 \\
\hline & 2011 & 9,6 & 16,7 & 22,0 & 23,3 & & 17,9 \\
\hline & 2012 & 12,3 & 19,7 & 21,6 & 24,2 & & 19,5 \\
\hline & $\begin{array}{l}\text { Average } \\
\text { indicator } \\
\text { for many } \\
\text { years }\end{array}$ & 7,9 & 14,7 & 18,1 & 19,8 & & 15,1 \\
\hline
\end{tabular}

Maximum productivity of naked oats plants without seeds inoculation -3.92 $\mathrm{t} /$ ha was obtained on the full fertilizer dose background with fluctuations in yield from 3.42 to $4.24 \mathrm{t} / \mathrm{ha}$. Application of Polymyxobacteryn had resulted in $4.2 \mathrm{t} / \mathrm{ha}$ with a range from $3.8 \mathrm{t} / \mathrm{ha}$ to $4.48 \mathrm{t} / \mathrm{ha}$. The highest grain yield was obtained in a favorable by the moisture values 2012 .

By decreasing the fertilizer dose from $\mathrm{N}_{60} \mathrm{P}_{60} \mathrm{~K}_{60}$ to $\mathrm{N}_{40} \mathrm{P}_{40} \mathrm{~K}_{40}$ (Table 3) the yield of oats had also decreased significantly to $0.61 \mathrm{t} / \mathrm{ha}$. Further reduction of fertilizer dose to $\mathrm{N}_{20} \mathrm{P}_{20} \mathrm{~K}_{20}$ had led to an average for the three years yield at 2.63 $\mathrm{t} / \mathrm{ha}$ (lower by $1.29 \mathrm{t} / \mathrm{ha}$ ), which is compared to the background control variant is, respectively, $84 \%$ and $67 \%$.

Seeds inoculation with Polymyxobacterynom on $\mathrm{N}_{60} \mathrm{P}_{0} \mathrm{~K}_{60}$ background had led to $2,64 \mathrm{t} /$ ha yield. The same level of productivity was obtained in variant with $\mathrm{N}_{20} \mathrm{P}_{20} \mathrm{~K}_{20}$.

At the increased content of mobile phosphorus on medium cultivated sodpodzolic soil type the impact of inoculation of naked oats seeds with Polymyxobacteryn was equivalent to the effect of $\mathrm{N}_{20} \mathrm{P}_{20} \mathrm{~K}_{20}$ dose of fertilizer, which application costs were 400-410 UAH/ha. The costs for biological preparation was 10 times lower, which is of big importance under the limited resources conditions. 
Table 3. Productivity naked oats depending from fertilizing systems and bacterization

\begin{tabular}{|c|c|c|c|c|c|c|}
\hline \multirow[t]{2}{*}{ \# } & \multirow[t]{2}{*}{ Variant } & \multicolumn{3}{|c|}{ Yield, $\mathrm{t} / \mathrm{ha}$} & \multirow{2}{*}{$\begin{array}{l}\text { Average, } \\
\text { t/ha }\end{array}$} & \multirow{2}{*}{$\begin{array}{l}\text { Increment } \\
\text { to control, } \\
\%\end{array}$} \\
\hline & & 2010 & 2011 & 2012 & & \\
\hline \multicolumn{7}{|c|}{ Without inoculation (background I) } \\
\hline 1 & $\begin{array}{l}\mathrm{N}_{60} \mathrm{P}_{60} \mathrm{~K}_{6} \\
0\end{array}$ & 4,11 & 3,42 & 4,24 & 3,92 & 100 \\
\hline 2 & $\begin{array}{l}\mathrm{N}_{60} \mathrm{P}_{40} \mathrm{~K}_{6} \\
0\end{array}$ & 3,42 & 3,02 & 3,56 & 3,33 & 85 \\
\hline 3 & $\begin{array}{l}\mathrm{N}_{60} \mathrm{P}_{20} \mathrm{~K}_{6} \\
0\end{array}$ & 3,02 & 3,00 & 3,30 & 3,11 & 79 \\
\hline 4 & $\mathrm{~N}_{60} \mathrm{P}_{0} \mathrm{~K}_{60}$ & 2,56 & 2,40 & 2,72 & 2,56 & 65 \\
\hline 5 & $\mathrm{~N}_{40} \mathrm{P}_{40} \mathrm{~K}_{4}$ & 3,16 & 3,12 & 3,64 & 3,31 & 84 \\
\hline 6 & $\begin{array}{l}\mathrm{N}_{20} \mathrm{P}_{20} \mathrm{~K}_{2} \\
0\end{array}$ & 2,40 & 2,48 & 3,02 & 2,63 & 67 \\
\hline 7 & $\mathrm{~N}_{0} \mathrm{P}_{0} \mathrm{~K}_{0}$ & 1,48 & 2,02 & 1,64 & 1,71 & 44 \\
\hline \multicolumn{7}{|c|}{ With inoculation (background 2) } \\
\hline 1 & $\begin{array}{l}\mathrm{N}_{60} \mathrm{P}_{60} \mathrm{~K}_{6} \\
0\end{array}$ & 4,32 & 3,80 & 4,48 & 4,20 & 107 \\
\hline 2 & $\begin{array}{l}\mathrm{N}_{60} \mathrm{P}_{40} \mathrm{~K}_{6} \\
0\end{array}$ & 4,30 & 3,90 & 4,56 & 4,25 & 108 \\
\hline 3 & $\begin{array}{l}\mathrm{N}_{60} \mathrm{P}_{20} \mathrm{~K}_{6} \\
0\end{array}$ & 3,30 & 3,56 & 3,62 & 3,49 & 89 \\
\hline 4 & $\mathrm{~N}_{60} \mathrm{P}_{0} \mathrm{~K}_{60}$ & 2,42 & 2,56 & 2,94 & 2,64 & 67 \\
\hline 5 & $\begin{array}{l}\mathrm{N}_{40} \mathrm{P}_{40} \mathrm{~K}_{4} \\
0\end{array}$ & 3,56 & 4,16 & 4,08 & 3,93 & 100 \\
\hline 6 & $\begin{array}{l}\mathrm{N}_{20} \mathrm{P}_{20} \mathrm{~K}_{2} \\
0\end{array}$ & 3,40 & 3,20 & 3,64 & 3,41 & 87 \\
\hline 7 & $\mathrm{~N}_{0} \mathrm{P}_{0} \mathrm{~K}_{0}$ & 3,10 & 2,88 & 3,04 & 3,01 & 77 \\
\hline \multicolumn{2}{|c|}{$\begin{array}{l}\mathrm{LSD}_{05} \\
\text { experiment }\end{array}$} & 0,23 & 0,19 & 0,20 & & \\
\hline \multicolumn{2}{|c|}{ for backgrounds } & 0,11 & 0,13 & 0,15 & & \\
\hline \multicolumn{2}{|c|}{$\begin{array}{l}\text { for inoculation } \\
\text { and interaction }\end{array}$} & 0,11 & 0,11 & 0,12 & & \\
\hline
\end{tabular}

The other important statement, which comes from the research results is that inoculation of naked oats seeds with Polymyxobacteryn is not practical to apply on the background of full fertilizer dose $\mathrm{N}_{40} \mathrm{P}_{40} \mathrm{~K}_{40}$. On background without inoculation the increase of fertilizer dose from $\mathrm{N}_{40} \mathrm{P}_{40} \mathrm{~K}_{40}$ to $\mathrm{N}_{60} \mathrm{P}_{60} \mathrm{~K}_{60}$ ensures extra $0,6 \mathrm{t} /$ ha yield, equivalent in economic terms to $1200 \mathrm{UAH}$, while the cost of $\mathrm{N}_{20} \mathrm{P}_{20} \mathrm{~K}_{20}$ dose of fertilizer in the form of nitroammophoska is 550-600 UAH. 
Thus, inoculation allows to save $650-600$ USD per hectare with oats.

Along with the search for the optimal combination of Polymyxobacteryn and full fertilizer the possibility of unbalanced phosphorous introducing at oats cultivation as well as possibility of technical phosphorus replacement with the metabolic by-products of preparation's biological agent (Table 3, variants 5, 6, 7 compared to the variant 1 ).

It was established that reduction of the phosphorus dose from $\mathrm{P}_{60}$ to $\mathrm{P}_{40}$ as part of a full fertilizer had led to a decrease in grain yield of naked oats in average for three years by $15 \%$, at decrease to $\mathrm{P}_{20}-21 \%$ while complete exclusion of phosphorus leads to a $35 \%$ decrease in yield.

In variants with Polymyxobacteryn the yield upon the complete fertilizer dose was $4.2 \mathrm{t} / \mathrm{ha}$, which was higher than in control variants by $7 \%$. In variant $\# 5$, with technical phosphorus dose reduced to $\mathrm{P}_{20}$ the yield was 3.93, on the level of control; $\mathrm{P}_{20 \mathrm{v}}$ at the normal nitrogen and potassium dose (variant \#6, background 1) the yield was $3.41 \mathrm{t} / \mathrm{ha}$, which corresponds to the yield level in variant \#5, background 1 with full $\mathrm{P}_{40}$ dose as a part of a complete fertilizer. At complete exclusion of phosphorus (variant 7) at seeds inoculation - the oats yield was 3.01 $\mathrm{t} / \mathrm{ha}$, equivalent to the yield level in variant \#6 (productivity level $-77-79 \%$ compared to control).

The ability of Polymyxobacteryn to reduce losses of nutrients, humic substances and moisture was examined in stationary lyzometric experiment.

\section{Table 4. The losses of nutrients, humic substances (kg/ha) and moisture (mm) at growing of naked oats (lyzimetric studies)}

\begin{tabular}{|c|c|c|c|c|c|c|c|c|c|}
\hline \multirow[t]{2}{*}{ Variants } & \multirow{2}{*}{$\begin{array}{l}\text { Yield, } \\
\text { t/ha }\end{array}$} & \multicolumn{8}{|c|}{ Losses } \\
\hline & & $\begin{array}{l}\text { Mo- } \\
\text { is- } \\
\text { ture }\end{array}$ & $\begin{array}{l}\text { Water } \\
\text { soluble } \\
\text { humus }\end{array}$ & $\mathrm{CaO}$ & $\mathrm{MgO}$ & $\mathrm{NO}_{3}$ & $\mathrm{NH}_{4}$ & $\mathrm{P}_{2} \mathrm{O}_{5}$ & $\mathrm{~K}_{2} \mathrm{O}$ \\
\hline \multicolumn{10}{|c|}{2011} \\
\hline $\mathrm{N}_{60} \mathrm{P}_{60} \mathrm{~K}_{60}$ (control) & 2,86 & 12,0 & 14,5 & 40,5 & 14,0 & 20,4 & 1,4 & 4,0 & 6,0 \\
\hline $\begin{array}{l}\mathrm{N}_{60} \mathrm{P}_{60} \mathrm{~K}_{60}+ \\
\text { Polymyxobacteryn }\end{array}$ & 3,10 & 8,0 & 8,0 & 30,4 & 10,4 & 18,0 & 0,8 & 4,0 & 4,8 \\
\hline $\mathrm{LSD}_{05}$ & 0,014 & 0,03 & 0,03 & 2,4 & 0,14 & 0,15 & 0,02 & 0,01 & $\begin{array}{l}0,0 \\
1\end{array}$ \\
\hline \multicolumn{10}{|c|}{2012} \\
\hline $\mathrm{N}_{60} \mathrm{P}_{60} \mathrm{~K}_{60}$ (control) & 4,02 & 14,0 & 12,0 & 36,0 & 12,0 & 24,6 & 2,5 & 3,2 & 4,6 \\
\hline $\begin{array}{l}\mathrm{N}_{60} \mathrm{P}_{60} \mathrm{~K}_{60}+ \\
\text { Polymyxobacteryn }\end{array}$ & 4,60 & 10,1 & 9,4 & 28,5 & 9,6 & 19,5 & 2,4 & 3,0 & 4,0 \\
\hline $\mathrm{LSD}_{05}$ & 0,024 & 0,02 & 0,02 & 1,3 & 0,10 & 0,12 & 0,02 & 0,01 & $\begin{array}{l}0,0 \\
1\end{array}$ \\
\hline
\end{tabular}

The studies had confirmed the possibility of technical phosphorus replacing $\left(\mathrm{P}_{20}\right)$ with seeds inoculation with Polymyxobacteryn which ensured efficient use of 
water by bacterized oats plants, calcium, magnesium, nitrogen and, respectively, a significant decrease of these elements runoff to groundwater due to infiltration (Table 4).

Thus, the pre-sowing seeds inoculation with Polymyxobacteryn in the technology of naked oats cultivation is an important resource saving factor with sufficiently high economic effect. 